\title{
Bachelor's Degree Completion
}

National Cancer Institute

\section{Source}

National Cancer Institute. Bachelor's Degree Completion. NCI Thesaurus. Code C70555.

Indicates that a person has received a degree for successful completion of a prog ram of studies that normally requires at least 4-5 years of full-time equivalent college-level work. 